\title{
'A Generational Earthquake'? An Analysis of the 2002 Presidential Election in South Korea
}

\author{
CARL J. SAXER
}

\begin{abstract}
The 2002 presidential election in South Korea was seen by some commentators as a 'generational earthquake'. It was argued that younger voters, defined as those belonging to the 20-30 age groups, had become more mobilized and active than in any previous election, and that consequently the persistent regionalism that had characterized South Korean national elections for so long was finally at an end. It was also claimed that the 2002 election marked a repositioning of ideology and policy preferences at centre stage. The present article, however, argues that while ideology and policy preferences did indeed assume greater importance, and while generational issues also came to the fore, yet the predominant factor in the 2002 election remained - as in previous presidential elections in South Korea - a persistent, almost static, regional voting pattern.
\end{abstract}

\section{Introduction}

At the time of writing in December 2003, the current South Korean president, Roh Mu-hyun, has just been defeated by a two-thirds majority in his attempt to veto a law passed by the National Assembly to appoint a Special Prosecutor to investigate allegations of corruption. ${ }^{1}$ In addition, Roh's call for a national referendum to be held in mid-December on the nation's confidence in him as leader has been put on hold.

There have been a number of events leading up to the present situation. First was the president's resignation as a member of the ruling Millennium Democratic Party, under whose banner he was elected president in December 2002. Second, there have been a number of corruption cases among the higher echelons of government. Finally, and no doubt as a direct consequence, the president has witnessed a marked drop in his approvals rating as leader - from 80 percent immediately after his inauguration to less than 30 percent in October 2003. In addition, while initially hopes were high that relations between the government and workers would see a marked improvement under Roh, a series of large-scale strikes have undermined confidence that this will in fact happen. 
These events have all but paralyzed the Roh administration, not only in its attempts to enhance inter-Korean relations through the Peace and Prosperity Policy but also to drive through measures for continued economic growth in South Korea. ${ }^{2}$ Foreign and economic policy in Korea is very much controlled by the president, who presently lacks a majority in the National Assembly, and is thereby greatly constrained in his efforts as leader to make progress in both economic and political arenas. Indeed Roh has to a great extent been sidetracked by the time he has been obliged to spend defending himself against allegations of corruption. He has therefore been unable to provide the leadership necessary to pursue the possibilities for increased economic and political exchanges between the south and the north after the 2000 Summit between Kim Dae-jung and Kim Jong-Il. The 'lame duck' status of the president has also meant that the economic reforms begun after the 1997 financial crisis have ground to a halt, as Roh has failed to get the necessary legislation passed, owing to his acrimonious relationship with the opposition.

However, the situation is certainly not a new one: other South Korean presidents have resigned from their parties, in fact every president elected since 1987 has chosen to resign from the ruling party. Often this has happened during the final year of the presidential tenure for a couple of reasons: first, so that the president may officially adopt a neutral stance vis-à-vis the deliberations for a new presidential candidate and, second, so that he may head a non-partisan government during the election year. Roh Tae-woo (1988-93), the first post-transition president, promised at the time of his inauguration that he would hold a referendum on his policies at mid-term. So although Roh did not fulfil this promise, this does at least set a precedent for holding a referendum on the performance of the president. However, we are only one year into Roh Mu-hyun's presidential tenure, and he is a president without significant party support in the National Assembly, in a presidential system not well disposed to accommodating such uneasy bedfellows. The previous president, Kim Dae-jung, also headed a minority government, and as a consequence saw most of his reforms blocked by the National Assembly. By the end of his tenure, Kim also had witnessed a significant erosion of his popularity due to several corruption cases involving not only close advisers but also his sons. Consequently in his last year in office, Kim became effectively a lame duck. In addition, as the South Korean constitution does not allow for a second term, political loyalties tend to shift from the incumbent president to leading candidates for the ruling party nomination. However, as Roh Muh-hyun has spent only one year in the Blue House and lacks majority 
support in the National Assembly, the political and economic reforms that he initiated are fast running out of steam.

Roh Mu-hyun was the surprise winner of an election which some commentators viewed as a 'generational earthquake'. ${ }^{3}$ Other commentators see things differently; they argue that it testifies to a 'widening ideological gap' in South Korean politics and that political preferences are finally beginning to influence voter choice. ${ }^{4}$ In 2001, the vast majority of political commentators expected Lee Hoi-chang, leader of the conservative Grand National Party and runner-up in the 1997 election, to carry the day come election; after all, opinion polls clearly showed him as the people's favourite no matter who stood against him. Even as late as six weeks before the 19 December election, a survey conducted by the daily newspaper, Chosun Ilbo, showed Lee ahead of the runner-up, Chung Mong-joon of the National Alliance 21, by more than 13 points. ${ }^{5}$ The survey indicated that even if Chung Mong-joon and Roh Mu-hyun (who was standing for the Millennium Democratic Party (MDP) and was then in third place) were able to reach agreement and come up with a joint candidate, Lee Hoi-chang would still win the election.

Although democratic national elections are often seen as an opportunity to 'vote the rascals' out of office, in fact they serve multiple purposes: as conduits to power and as the aggregation of public preferences. As such, it is expected that the voter will make their choice based to a large extent on political preferences. ${ }^{6}$ However, historically, elections in South Korea have always been decided not on the policies of the candidates, but on regional preferences. In fact, since the first post-transition election in December 1987, and even before that, there has been a persistent, almost static, regional voting pattern where voters are swayed not by the political views and policies of the candidates, but by their regional origin. ${ }^{7}$ Combined with a significantly higher turnout by older voters and an electoral system heavily weighted towards rural voters, this lock-in of a sizeable percentage of the votes augured success for the conservative ruling party candidates coming from the most populous provinces, the Kyungsang Provinces, in both the 1987 and 1992 elections. While structural and class issues of course should come to the fore in a country as highly industrialized as Korea, repression during the authoritarian period (1961-87) prevented any labour-based party from participating in the National Assembly or in the few presidential elections that were held during that period. ${ }^{8}$ Labour candidates have participated in elections since 1987, but in most cases they received less than 2 percent of the vote, and consequently the parties were dissolved by law. ${ }^{9}$ 
Although we saw a power alternation in 1997 with perennial opposition candidate Kim Dae-jung winning the election, that election too underlined yet again the importance of regional origins as Kim Dae-jung received more than 90 percent of the votes in his home province, and he was only able to clinch the victory due to a fragmented opposition and a coalition with another regionally based party led by Kim Jong-pil. ${ }^{10}$

The presidential election in 2002, on the face of it, promised to be different. None of the major candidates seemed to have the same regional pull as the three Kims and none of the candidates in fact stood as candidate for a party traditionally based in his home region. ${ }^{11}$ It was therefore expected that the sway of regionalism would be significantly diminished and that the 2002 election would serve as a watershed in the way elections would henceforth be fought and won in South Korea.

Through a detailed analysis of the 2002 election, this article investigates if behind the surprising victory by Roh Mu-hyun there was in fact a 'generational earthquake', a sign of the 'widening ideological gap' in Korean politics, or if we must look elsewhere to find the root causes for Roh's victory. The article argues that while the election showed evidence of a generational voting pattern, in addition to the emergence an ideological cleavage, yet these two factors alone cannot explain the outcome of the election. While these developments certainly influenced Roh's victory, as in previous presidential elections in South Korea, the most indicative explanation remains that of the regional voting pattern. Nonetheless, the evidence does suggest that if the current developments continue, we may soon witness a diminution in the importance of regional voting in South Korea and the establishment of a policy-based institutionalized party system.

\section{Shifting Patterns? The 2002 Election}

It was not at all certain that Roh Mu-Hyun would be nominated as the ruling Millennium Democratic Party's (MDP) candidate for the 2002 election. In fact, Rhee In-je, who had run against Kim Dae-jung in 1997 and joined the MDP in 1998, was considered by many as a much more credible candidate. However, as the different factions within the ruling party could not reach a consensus, and seeking to expand democracy within the party, Kim Dae-jung agreed to let the MDP change the nomination rules toward an American-style primary. Consequently in January 2002, 70,000 delegates (half of whom were from the party membership and half randomly selected from the populace at large) participated in nationwide primaries. The initial handful of 
candidates was, through intra-party competition, soon narrowed down to two candidates: Roh Mu-hyun, a human rights lawyer with scant experience of national not to mention international politics, and Rhee In-je, a politician better known for frequently changing parties than for his policies. However, Rhee soon withdrew from the race amid persistent rumours that the president was behind the candidacy of Roh. Rhee's problem was that he was simply unable to match Roh's regional support; moreover he soon came under pressure from party leaders who doubted his ability to win against Lee Hoi-chang. ${ }^{12}$

Although Roh Mu-hyun was respected for his honesty and work for human rights, he did not have significant experience in government. In January 2002, as the race for the presidency was only just beginning to warm up, Roh was more than 25 percentage points behind the leader, Lee Hoi-chang, who enjoyed a far higher profile as a politician. However, the increasing and mainly favourable attention by the media on the ruling party nomination process meant that by February Roh was becoming better known. Furthermore his key supporters, known as 'The 386 Generation', began to use the internet to publicize their political views and drum up support for Roh. ${ }^{13}$ Unlike the elections held before the Asian crisis of 1997, the 2002 election witnessed, in common with the 1997 election to a certain degree, only limited usage of large outdoor rallies by both the ruling party and the opposition. ${ }^{14}$ Instead the opposing camps attempted to take advantage of the widespread use of the internet in South Korea (South Korea had the highest penetration rate in the world). In particular, Roh's young advisers began to see the advantage of using this as an instrument to reach potential voters. ${ }^{15}$

The purpose was to target those segments of society that surveys indicated as more favourably inclined towards the liberal views of Roh. ${ }^{16}$ An internet site established in the spring of 2000, Nosamo.org ('people who love Roh Mu-hyun'), initially counted just 300 members, but by May 2002 the figure had grown to more than 36,000. The site was used not only to promote Roh's ideas and policies, but also to mobilize people's support for the nomination campaign; indeed, this was a major factor behind Roh's success in winning the ruling party nomination at the end of April. After that time, the people running the site began to focus their attention on younger voters, in an attempt to motivate them to turn out at the polls come December. In fact, the site was so successful in raising interest that by December the site had more than half a million hits a day and Roh was receiving through the site more than 7,000 emails a day. 
However, events took a different turn when it emerged that several close advisers to Kim Dae-jung, and even his two sons, had been involved in corruption scandals. Local elections saw the Grand National Party (GNP) crushing the ruling party as most mayoral and gubernatorial posts were won by the GNP. ${ }^{17}$ The election also had the lowest turnout thus far recorded in South Korea, and by the autumn 2002 all surveys still showed Roh lagging behind not only Lee Hoi-chang but also Chung Mong-joon, a new candidate on the political scene. ${ }^{18}$ Chung Mong-joon was son of the Hyundai chaebŏl founder and the richest member of the National Assembly, and he sought to capitalize on the existing status and recognition he already enjoyed as head of the Korean Football Association, and on the visibility he had gained during the very successful 2002 World Cup. ${ }^{19}$ By mid-September Chung, as leader of the newly organized National Unity 21, was running in second place in the polls and was only half a percentage point behind the front-runner, Lee Hoi-chang, but comfortably ahead of the ruling party's candidate Roh Mu-hyun. Realizing that he would not be able to beat Lee singlehandedly, by September he had begun discussions with Roh to see if they could agree on a joint candidate. Despite a series of negotiations, the two parties failed to reach an agreement, and fearful of dividing the liberal vote (in the way that Lee Hoi-chang and Rhee In-je had split the conservative vote in 1997 and Kim Dae-jung and Kim Young-sam the liberal one in 1987, in both cases leading to defeat), Roh Mu-hyun and Chung Mong-joon decided to take the matter to the people through a number of polls following a televised debate. ${ }^{20}$

The talks over the format of the televised debate and the polls, however, hit a snag on 18 November, as National Unity 21 demanded that a key negotiator from the MDP, who had leaked the planned date of the polls, be removed from further talks. ${ }^{21}$ Chung Mong-joon also took issue with the wording of the poll question. Fearing Roh's eloquence, the Chung camp had demanded that the question be asked in such a way that would indicate voter preference for the candidate, rather than who the voters thought had won the televised debate. It was on 22 November, after these issues had been resolved, that the debate was held. ${ }^{22}$ Postdebate surveys conducted by the media indicated that the two were running neck and neck, and the three days between the televised debate and the poll taking were spent on vigorous campaigning, mainly in the Cholla Provinces which were seen as key to victory in the polls. ${ }^{23}$ After a series of secret opinion polls conducted in the days immediately after the debate, it was announced that Roh Mu-hyun 
would stand as the joint candidate. Surveys carried out immediately after the announcement showed a significant jump in support for Roh. Consequently the GNP changed its campaign strategy in an attempt to emphasize the ideological differences between the liberal Roh and the conservative GNP candidate. ${ }^{24}$ The announcement that Roh would be the joint candidate established him almost overnight at the front-runner in the surveys, a position that he would retain until election day.

FIGURE 1: 2002 Presidential Election Surveys (main candidates)

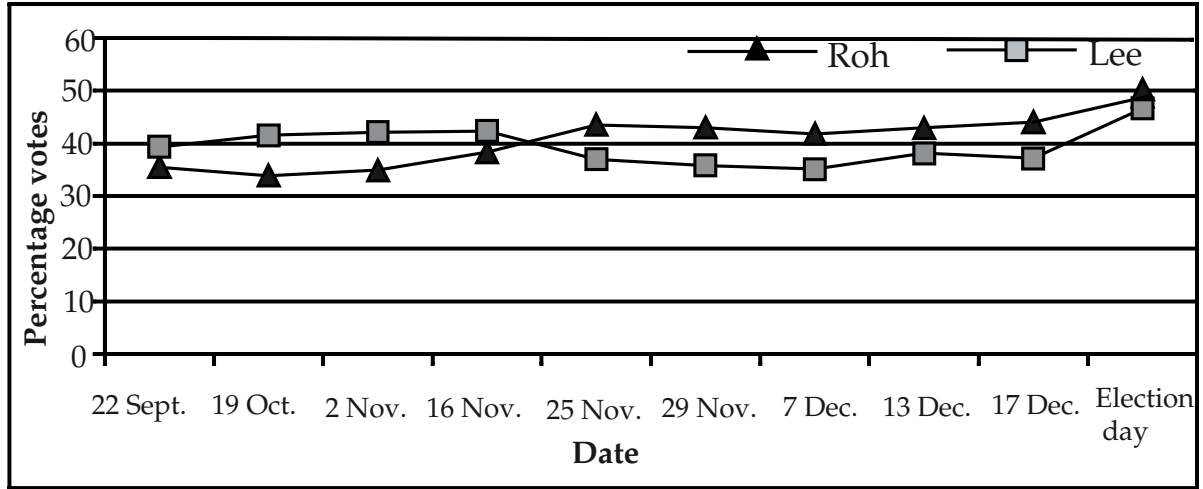

Sources: Korea Gallup, Media Release 136 (2002); Media Research (2002).

In contrast to the nomination process of the ruling MDP, it had never been in doubt that Lee Hoi-chang would become the GNP's candidate even after losing the presidential election in 1997 to Kim Dae-jung. Consequently, on 10 May Lee was officially declared his party's presidential candidate. Fearing the established support Lee commanded among the voters, the ruling MDP, as in 1997, again attempted to undermine his popularity by raising the issue of Lee's sons having avoided military service on the grounds that they were underweight. ${ }^{25}$ The MDP even charged that people close to Lee had attempted to cover up the illegal evasion of military service by bribing military officials. Although official investigations indicated that these allegations might prove to be unfounded, they nonetheless, as in 1997, damaged Lee's reputation especially among younger voters who were tired of the sons of the rich avoiding compulsory military service. In contrast, Roh Mu-hyun saw a significant increase in his support among younger votes during the three weeks prior to the election, and by late November surveys showed him supported by 55 percent of those in the 20-29 age cohort and by 50 percent of the 30-39 age cohort. ${ }^{26}$ This shift was important as voters in their twenties and thirties constituted more than 48 percent of the electorate. ${ }^{27}$ 
However, while Roh saw his support among younger voters rise, in South Korea, as in most industrialized democracies, younger voters tend to have significantly lower turnout rates, making an efficient campaign to reach these age groups vital to the success of the Roh campaign. ${ }^{28}$ Taking advantage of the high penetration rate of the internet in South Korea, the Roh camp sought to use this as an instrument to reach out to younger voters. ${ }^{29}$

There were two principal reasons for the rise in Roh's popularity among younger voters: first, the agreement between Roh and Chung Mong-joon on a joint candidate, and second, the significant anti-American sentiment among younger voters due to the killing of two young school-girls by an armoured vehicle driven by two US servicemen. Roh was much more able, and willing, to score political points from the public outcry at the failure to prosecute the two US soldiers in a South Korean court and their subsequent acquittal in a US military court. Roh's campaign speeches, which as the campaign heated up in the autumn of 2002, began increasingly to question South Korea's ties with the US, were well received by many, especially younger voters. Surveys showed that not only were a majority of younger voters increasingly liberal in their political viewpoints, they were also more inclined to be anti-American than older voters. ${ }^{30}$ Although Lee Hoi-chang tried also to clamber aboard this platform, even demanding a 'personal apology' from the US president, Roh, who in the 1980s and 1990s had called for the complete removal of US troops from South Korea, came across with far more credibility on the issue that his more established conservative opponent. ${ }^{31}$ Roh also declared that he would not travel to Washington to 'kowtow' to the US president, and that he would, if elected, continue the Sunshine Policy begun under Kim Dae-jung. The Sunshine Policy enjoyed significant support in the population at large, but especially among younger voters who increasingly refused to see North Korea as a military threat. ${ }^{32}$ These voters insisted on a more conciliatory tone in relations with North Korea. Many of them were deeply influenced by US inaction during the suppression of the people's uprising in May 1980 in Kwangju and they viewed US influence in South Korea as a relic of the Cold War.

The agreement between Chung Mong-joon and Roh Mu-hyun had stipulated that whoever lost at the polls should subsequently actively support the campaign of the winner. However Chung, while pledging to fight against Lee, gave lukewarm support at best to Roh's campaign, despite numerous pleas from the Roh camp. Chung then, only a few hours before the end of the official campaign period, abruptly withdrew his support from Roh. However, this does not seem to have damaged 
Roh's prospects at the polls, indeed it might even have helped him, as his supporters became even more determined to turn out to vote. And while the announcement by North Korea in mid-December that it would reactivate its nuclear programs would, under normal circumstances, increase the conservative vote and play into the hands of Lee Hoi-chang, surveys conducted in the days after the North Korean announcement showed only minuscule changes in voter support. ${ }^{33}$

The election on 19 December 2002 saw the lowest ever turnout for a presidential election in South Korea and so continued a trend initiated at the first post-transition election (Table 1).

TABLE 1: Voter Turnout at Post-Transition Presidential Elections

\begin{tabular}{|l|c|c|c|c|}
\hline Year & 1987 & 1992 & 1997 & 2002 \\
\hline Voter turnout (\%) & 89.9 & 81.9 & 80.7 & 70.8 \\
\hline
\end{tabular}

Sources: Ch'oi 1996: 401; National Election Commission at http:/ /www.nec.go.kr

Even Kwangju and the Cholla provinces, which constituted the main support base of the MDP, although still above the national average, witnessed a significant drop in voter turnout compared to 1997 (Table 2).

TABLE 2: Voter Turnout (\%) at Presidential Elections in Kwangju and the Cholla Provinces (1997 and 2002)

\begin{tabular}{|l|c|c|}
\hline Area/Year & $\mathbf{1 9 9 7}$ & $\mathbf{2 0 0 2}$ \\
\hline Kwangju & 89.9 & 78.1 \\
\hline South Cholla Province & 87.3 & 76.4 \\
\hline North Cholla Province & 85.5 & 74.6 \\
\hline
\end{tabular}

Source: National Election Commission at http:/ /www.nec.go.kr

Winning the election with 48.9 percent of the vote against Lee's 46.6 percent, the election continued another trend that first began in 1987, namely that of electing a president with less than a majority of the votes. ${ }^{34}$ Leading a minority government in a presidential system not designed to accommodate such a situation, Roh found himself from the outset sailing in rough waters. Indeed, throughout his first year in office, he has been fighting an uphill battle to get his policies through a National Assembly controlled by a GNP out for revenge after their defeat in the presidential election.

Table 3 seems to establish that compared to Kim Dae-jung in 1997, the Roh camp was in a far better position to appeal to, and mobilize, the younger voters. 
TABLE 3: Longitudinal Comparison of Electoral Choice by Age Cohort

\begin{tabular}{|c|c|c|c|c|}
\hline $\begin{array}{c}\text { Age } \\
\text { Cohort }\end{array}$ & $\begin{array}{c}\text { Kim Dae-jung } \\
\mathbf{1 9 9 7}\end{array}$ & $\begin{array}{c}\text { Lee Hoi-chang } \\
\mathbf{1 9 9 7}\end{array}$ & $\begin{array}{c}\text { Lee Hoi-chang } \\
\mathbf{2 0 0 2}\end{array}$ & $\begin{array}{c}\text { Roh Mu-hyun } \\
\mathbf{2 0 0 2}\end{array}$ \\
\hline $20-29$ & 43.2 & 27.9 & 31.7 & 62.1 \\
\hline $30-39$ & 43.7 & 34.8 & 33.9 & 59.3 \\
\hline $40-49$ & 37.2 & 44.1 & 48.7 & 47.4 \\
\hline $50+$ & 34.2 & 51.0 & 58.3 & 39.8 \\
\hline
\end{tabular}

Sources: Hangukgaellŏp josa yŏnguso 1998:19; MBC-TV exit poll published in The Korea Herald, 20 December 2002 (internet edition).

Tables 4 and 5 also suggest that regional sentiment was an even more important factor than age in the candidates' home regions. There is, for instance, hardly any difference across age in the support for Roh $\mathrm{Mu}$ hyun in his home region of Kwangju/Cholla Provinces. However, the evidence also indicates that Roh was able to expand his appeal among younger voters especially in the larger cities, but also to a lesser degree even in areas where voters in general supported Lee Hoi-chang. Lee, on the other hand, was clearly unable to convince elderly voters in Roh's home region to support him.

TABLE 4: Cross-tabulation of Regional Votes by Age Cohort (Roh Mu-hyun)

\begin{tabular}{|l|c|c|c|c|}
\hline Region/Age Cohort & $\mathbf{2 0 - 2 9}$ & $\mathbf{3 0 - 3 9}$ & $\mathbf{4 0 - 4 9}$ & $\mathbf{5 0 +}$ \\
\hline Seoul & 70.6 & 60.7 & 40.9 & 38.8 \\
\hline Inchŏn/Kyunggi Province & 61.0 & 65.1 & 40.6 & 27.4 \\
\hline Kangwon Province & 79.5 & 48.6 & 32.1 & 26.1 \\
\hline Taegu/Ch'ungchong Province & 66.8 & 58.4 & 53.3 & 35.5 \\
\hline Kwangju/Cholla Province & 97.5 & 86.7 & 93.7 & 92.7 \\
\hline Taegu/North Kyungsang Province & 30.7 & 37.0 & 15.5 & 8.7 \\
\hline Pusan/Ulsan/South Kyungsang Province & 49.2 & 47.5 & 30.9 & 11.6 \\
\hline Chejudo & 66.7 & 78.4 & 56.7 & 25.0 \\
\hline
\end{tabular}

Source: See Table 5.

However, the fact that the year 2002 witnessed the lowest ever turnout at a presidential election, and that the drop was across all age groups, means that the mobilization of younger voters hardly suffices as an explanation as to why Roh was able to win the election. As Table 6 and Figure 2 indicate, any explanation for the 2002 election outcome must take into account the same regional voting pattern as in previous elections. In fact, it was the regional voting pattern, as evidenced in the city of Kwangju and the Cholla Provinces, where approximately 90 
TABLE 5: Cross-tabulation of Regional Votes by Age Cohort (Lee Hoichang)

\begin{tabular}{|l|c|c|c|c|}
\hline Region/Age Cohort & $\mathbf{2 0 - 2 9}$ & $\mathbf{3 0 - 3 9}$ & $\mathbf{4 0 - 4 9}$ & $\mathbf{5 0 +}$ \\
\hline Seoul & 21.2 & $\mathbf{2 9 . 8}$ & 53.7 & 59.0 \\
\hline Inchŏn/Kyunggi Province & 31.6 & 29.3 & 53.0 & 70.9 \\
\hline Kangwon Province & 13.7 & 32.2 & 65.0 & 70.8 \\
\hline Taegu/Ch'ungchong Province & 25.6 & 31.1 & 41.1 & 61.7 \\
\hline Kwangju/Cholla Province & 0.0 & 8.4 & 4.7 & 6.9 \\
\hline Taegu/North Kyungsang Province & 61.1 & 52.1 & 82.2 & 90.1 \\
\hline $\begin{array}{l}\text { Pusan/Ulsan/South Kyungsang } \\
\text { Province }\end{array}$ & 44.2 & 46.4 & 63.1 & 86.6 \\
\hline Chejudo & 16.4 & 14.3 & 43.3 & 75.0 \\
\hline
\end{tabular}

Source: Calculations based on surveys published in Hanguk gaellŏp josa yŏnguso 2003.

TABLE 6: Longitudinal Comparison of Regional Voting Pattern

1992: Percentage votes

\begin{tabular}{|l|c|c|}
\hline & Kim Young-sam & Kim Dae-jung \\
\hline Home region & 70.1 & 92.2 \\
\hline Outside home region & 31.1 & 22.7 \\
\hline National average & 41.9 & 33.8 \\
\hline
\end{tabular}

1997: Percentage votes

\begin{tabular}{|l|c|c|}
\hline & Kim Dae-jung & Lee Hoi-chang \\
\hline Home region & 94.7 & 61.7 \\
\hline Outside home region & 29.6 & 28.1 \\
\hline National average & 40.3 & 38.7 \\
\hline
\end{tabular}

2002: Percentage votes

\begin{tabular}{|l|c|c|}
\hline & Roh Mu-hyun & Lee Hoi-chang \\
\hline Home region & 93.4 & 71.4 \\
\hline Outside home region & 41.3 & 34.8 \\
\hline National average & 48.9 & 46.6 \\
\hline
\end{tabular}

Sources: Taehan Minguk Jŏngbu [Government of the Republic of Korea] 1993, 1988. The National Election Commission at http:/ / www.nec.go.kr. 
percent of voters across all age groups supported Roh, combined with his ability to appeal to younger voters even outside his home region, that won him the election.

Figure 2 establishes without question that a regional voting pattern has persisted since 1987, with Kim Dae-jung in 1987, 1992, and in 1997 dominating the Cholla Provinces and the city of Kwangju. While these areas are considered to have been, and remain, more liberally inclined in political orientation than other provinces, ideological preferences alone hardly can explain the overwhelming support that Kim, and now Roh, received in these areas. It is interesting to note that the loyal support enjoyed by Kim Dae-jung in these areas through three presidential elections, was transferred, at Kim's request, to Roh as the presidential candidate of the party founded by Kim.

FIGURE 2: Regional Voting Pattern: Kim Dae-jung (1987, 1992, and 1997) and Roh Mu-hyun (2002)

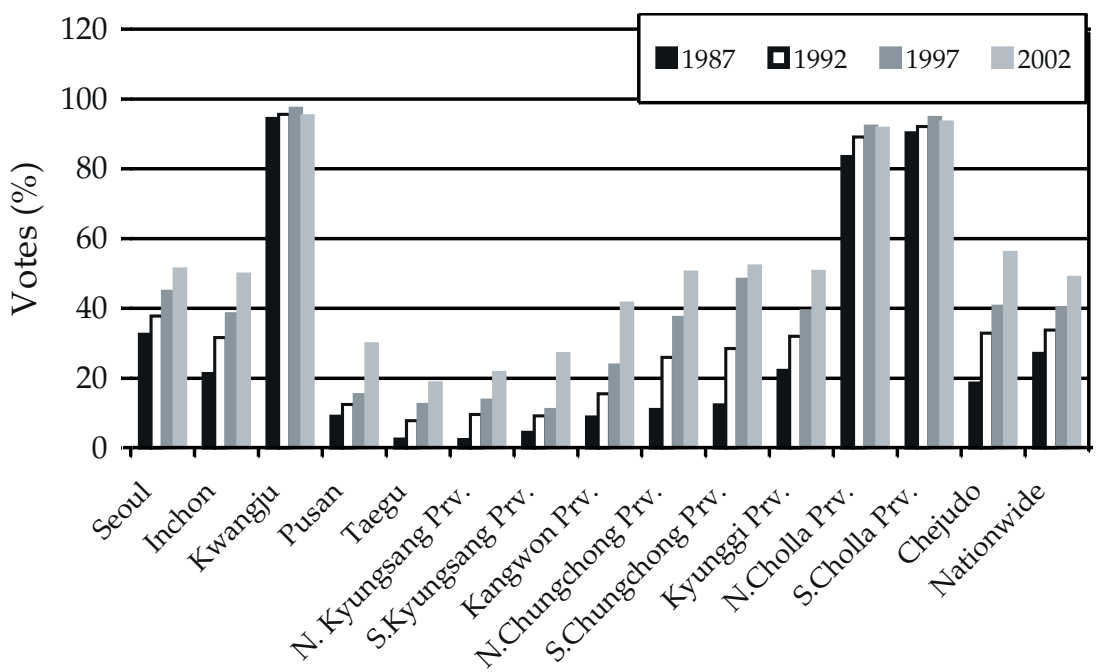

Cities and Provinces

Source: National Election Commission at http: / / www.nec.go.kr

The evidence clearly disproves that Roh's victory was due solely to a generational and ideological divide. Undoubtedly, a major factor remains the persistent regional voting pattern that has figured significantly in all elections in South Korea since the democratic transition in 1987, be they National Assembly or presidential elections. 


\section{Conclusion}

Although the 2002 election saw a similar regional voting pattern to earlier elections, the stark generational split in the candidates' support base will most likely continue to change the way the South Korean government views the world. From the viewpoint of foreign affairs, the country has shown that it will not uncritically follow the lead of the United States, especially on vital issues such as relations with North Korea. The 386 Generation has arrived in South Korean politics and, deeply influenced by their experience of the struggle for democracy in the 1980s, they are increasingly moving into positions of influence.

The evidence seems to suggest that while younger voters keen on political change definitely tempered regionalism in the 2002 election, yet turnout rates among those in their twenties remained low at only 47.5 percent in 2002 compared to 68 percent in 1997, while the turnout rate for those in their thirties was 68.2 percent in 2002 compared to 82.6 in 1997. While the internet definitely helped to generate interest in Roh, surveys conducted after the election indicate that the traditional media - television and newspapers - still were the sources people turned to when they wanted to learn about the presidential candidates. ${ }^{35}$ In addition, the less than impressive turnout rate of younger voters indicates only partial success in mobilizing this segment of the population. However, this may be part of a general trend, as indicated by Table 1, which reveals that presidential elections in Korea are seeing a significant drop in voter turnout across all age groups. ${ }^{36}$

Juan Linz and Alfred Stepan (1996) have in their seminal work warned us not to fall for the 'electoral fallacy'. ${ }^{37}$ By that they mean that although free, open and fair elections are a necessary condition for democracy, they are not a sufficient condition. Further necessary conditions, but not sufficient ones, include institutionalized representation and accountability, as Scott Mainwaring (1999) argues in his work on Brazil. Representation will often take place through political parties, but when these remain weakly institutionalized, personalism tends to dominate electoral campaigns and outcomes. ${ }^{38}$ This will in turn lead to weakened accountability. A consequence of this can be a 'delegative' democracy, defined by Guillermo O'Donnell as having four main characteristics: (i) a high degree of personalism, (ii) considerable power invested in the executive, (iii) weak institutions, and (iv) weak mechanisms of horizontal oversight. ${ }^{39}$ However, the endemic splits among the political parties, and their uneasy coexistence within the National Assembly seem to suggest that Korea is headed towards an extended period marked by a political 
impasse. Indeed, surveys indicate that the coming National Assembly election in April 2004 will fail to deliver a working majority for the president, and there are no signs that the opposition will abandon its policy of blocking all initiatives coming from the president.

The 2002 presidential election proved without a doubt that electoral democracy has now entered the mainstream political process in Korea. However, it also showed that Korean democracy has yet to become fully consolidated. There are a number of indications that point in this direction. First, a significant element of the political establishment, symbolized by the United Liberal Democrats led by Kim Jong-pil, remains unconvinced that the presidential system is the best one for a country such as Korea. Second, while there are indications of the increased importance of ideological and policy preferences, elections continue to show a persistent regional voting pattern. Third, the National Security Law, while used much more infrequently now against political opposition, remains on the statute books, thereby placing restrictions on free participation and inclusiveness. Fourth, although there remains strong support for democracy in principle, there are signs of a decrease in trust in democratic institutions, especially in the National Assembly. Finally, there was in 2002 widespread disregard for electoral rules and regulations, especially with regard to campaign expenses. ${ }^{40}$

One consequence of the presidential system and persistent regionalism is the lack of real institutionalization of political parties, as evidenced by the recent split of the MDP. The simple plurality presidential system currently used in South Korea does not encourage the institutionalization of parties, as winning has remained a question of regional origin and personality.

In conclusion, as with earlier presidential elections, and in fact also at National Assembly Elections, the decisive factor at the 2002 presidential election was a persistent regional voting pattern. Any movements towards cross-regional alliances and coalitions have traditionally been based not on policy convergence between different political parties, but on the need of regionally based political leaders to expand their electoral base outside their home region. However, the 2002 presidential election did indicate movement towards the establishment of a clear generational divide, demonstrating that the political spectrum has broadened considerably. Thus, while it may not have been a 'generational earthquake', yet the election definitely served as an important watershed in electoral politics in South Korea.

Carl J. Saxer is Assistant Professor, Department of Asian Studies, University of Copenhagen. He received his D.Phil from the University of Oxford. 


\section{NOTES}

1 The president announced on 13 December that if a special independent investigation were to establish that he received illegal campaign contributions exceeding by onetenth the amount collected illegally by the main opposition, he would resign as president. Chosun Ilbo, 14 December 2003.

2 Peace and Prosperity Policy is the new name for what in reality is nothing but the continuation of Kim Dae-jung's Sunshine Policy.

3 Financial Times, 23 December 2002, US edition: 8.

4 See for instance Hoon Jaung (2003: 8).

5 Chosun Ilbo, 11 November 2002 (internet edition).

6 For an interesting recent collection of papers on political parties, see Richard Gunther, José Ramón Montero and Juna J. Linz (eds) (2002).

7 It is quite normal for candidates to enjoy a certain regional home advantage. However, the regional voting pattern in Korea has seen Kim Dae-jung receive more than 90 percent of the votes in his home region, the Cholla Provinces and the city of Kwangju, in every election since 1987.

8 Direct presidential elections were held in 1963, 1967 and 1971. A close call in 1971 against Kim Dae-jung, saw President Park Chung-hee change the constitution to an indirect election by electoral college. The year 1987 witnessed the free direct election for president; it was also the year when the regional voting pattern was in evidence for the first time.

9 The T'onghab sŏngŏ pŏb [The Unified Election Law] mandates that political parties receiving less than 2 percent of the votes be dissolved.

10 For a detailed analysis of the 1997 election, see Saxer (2002).

11 By the three Kims is meant Kim Young-sam (r. 1993-98) from the Kyungsang provinces, Kim Dae-jung (r. 1998-2002) from the Cholla Provinces, and Kim Jong-pil from the Chungchong Provinces. Those three have dominated politics in South Korea for decades. Lee Hoi-chang was born in Hwanghae Province in present-day North Korea, but was seen as a member of the Seoul-based establishment, and Roh Mu-hyun, while born in South Kyungsang Province, was standing for a party which had its roots in the Cholla Provinces.

12 Rhee In-je later in May joined the United Liberal Democrats and called for support for a constitutional revision towards a parliamentary system.

13 The generation know as the 386 Generation was born in 1960s, went to college in the 1980s, and were in 2002 in their thirties or early forties. It is a generation deeply influenced by the struggle for democracy in the 1980s.

14 The 1997 presidential election saw 49 large outdoor rallies, while in 2002 less than five were held. The Korea Herald, 19 December 2002 (internet edition).

15 See The New York Times, 5 May 2003, p. C4.

16 A poll conducted among opinion leaders by the Joongang Ilbo indicated that the voters' attitudes, with the exception of those in their fifties and sixties, had shifted towards the liberal centre. See Joongang Ilbo, 11 February 2003 (internet edition).

17 Chosun Ilbo, 13 June 2002 (internet edition).

18 A Chosun Ilbo and Korea Gallup survey gave Lee Hoi-chang 31.3 percent, Chung Mong-joon 30.8 percent, and Roh Mu-hyun came in third with 16.8 percent. Survey quoted in Chosun Ilbo, 22 September 2002 (internet edition).

19 His father had run in 1992 and come third in the race won by Kim Young-sam.

20 In 1997 Kim Dae-jung received 40.3 percent of the votes against Lee Hoi-chang's 38.7 percent. Rhee In-je came a distant third with 19.2 percent. For detailed discussions of the 1987 and 1997 elections, see Saxer (2002).

21 Joongang Ilbo, 19 November 2002 (internet edition). The five National Unity 21 members of the negotiations committee quit their posts, arguing that the leak by the MDP negotiators had invalidated the agreement. They also accused the MDP of distorting the survey question. 
24 An opinion poll taken by the Munhwa Ilbo and the cable channel YTN showed Roh now leading Lee with 48.2 percent against 39.1 percent. See The Korea Times, 26 November 2002 (internet edition). With the announcement of Roh as a joint candidate, Lee Hoichang saw the election as 'a duel between conservatives and progressives', The Korea Times, 26 November 2002 (internet edition).

When the rumours first surfaced in 1997, Lee Hoi-chang claimed that one son was thin because of gastroenteritis and the other because he was at that time preparing his $\mathrm{PhD}$ dissertation in the US. However, this convinced very few people. In an attempt at heading off more damage to his reputation, Lee was forced to express regret over the controversy surrounding his two sons' military service. Within a few weeks of the allegations, Lee's popularity rating dropped more than 7 percent. See Hangukgaellŏp josa yŏnguso [Korean Gallup Poll] (1998). The drop was particularly large among people in their twenties and thirties. Again in 2002 when the accusations were aired, the result was a drop, this time less than 2 percent, in Lee's popularity. Korea Gallup, News Release 136, 2002. November 2002.

\section{REFERENCES}

Bae Han-dong 2001. Hanguk daehaksaengŭi jŏngch'iǔisik [The Political Attitudes of Korean Students]. Seoul: Jibmundang.

Chamberlin, Paul F. 2001. Korea 2000: The Challenges of the New Millennium. Washington D.C.: The Center for Strategic and International Studies.

Ch'oi Han-su 1996. Hanguksŏngŏjŏngch'iron [A Study on Korean Electoral Politics] Seoul: Taewangsa.

Chosun Ilbo, 22 September, 11 November, 6 December 2002 (internet edition).

Chosun Ilbo, 14 December 2003.

Financial Times, 23 December 2002, US edition: 8.

Gunther, Richard, José Ramón Montero, and Juna J. Linz (eds) 2002. Political Parties: Old Concepts and New Challenges. Oxford: Oxford University Press.

Hangukgaellŏp josa yŏnguso [Korean Gallup Poll] 1998. '97 je 15-dae taet'ongryŏng 
sŏngŏ t'upyohaengt'ae' [Trial Heats of the 15th Presidential Election in 1997]. Seoul: Hangukgaellŏp.

—2003. '02 je 16-dae taet'ongryŏng sŏngŏ t'upyohaengt'ae' [Trial Heats of the 16th Presidential Election in 2002]. Seoul: Hangukgaellŏp.

Hoon Jaung 2003. President Roh Moo-hyun and the New Politics of South Korea. New York: Asia Society.

Joongang Ilbo, 19 \& 23 November 2002, 11 February 2003 (internet editions).

Korea Gallup Poll 2002. News Release 136, 2002.

Korea Herald, 19 \& 20 December 2002 (internet edition).

Korea Times, 26 November, 13 \& 20 December 2002 (internet edition).

Lee Nam Young 2002. 'Generational Voting Patterns in Korea', Korea Focus 10 (6). Online edition at http://www.kofo.or.kr/KoreaFocus.

Linz, Juan J. and Alfred Stepan 1996. Problems of Democratic Transition and Consolidation: Southern Europe, South America, and Post-Communist Europe. Baltimore and London: Johns Hopkins University Press.

Mainwaring, Scott P. 1999. Rethinking Party Systems in the Third Wave of Democratization: The Case of Brazil. Stanford: Stanford University Press.

Media Research, 19 December 2002. Media Research, Seoul.

National Election Commission at http:/ / www.nec.go.kr

New York Times, 5 May 2003.

Oh, John Kie-Chiang 1999. Korean Politics: The Quest for Democratization and Economic Development. Ithaca and London: Cornell University Press.

Saxer, Carl J. 2002. From Transition to Power Alternation: Democracy in South Korea, 19871997. New York: Routledge.

Schmitter, Philippe C. and Terry Karl 1991. 'What Democracy Is ... and Is Not.' Journal of Democracy 2 (3): 75-82.

Shin Doh-Chull 1999. Mass Politics and Politics in Democratizing Korea. Cambridge: Cambridge University Press.

Taehan Minguk Jŏngbu [Government of the Republic of Korea] 1993. Je 14-dae taet'ongryŏng sŏngŏ ch' ongram [The 14th Presidential Election Results]. Seoul: Jungang sŏngŏ kwalliŭiwŏnhoe.

—1998a. Je 15-dae taet' ongryŏng sŏngŏ ch'ongram [The 15th Presidential Election Results] Seoul: Jungang sŏngŏ kwalliŭiwŏnhoe.

-1998b. Je 15-dae taet'ongryŏng sŏngŏ t'upyoyulbunsŏk [The 15th Presidential Election Voter Turnout Analysis]. Seoul: Ch'ŏnghwa.

Watts, William 2002. Next Generation Leaders in the Republic of Korea: Opinion Survey Report and Analysis. Washington D.C.: Potomac Associates.

Yi Hyŏn-u 1998. 'Hanguk-esŏ-ŭi kyŏngjet'up'yo' [Economic Voting in Korea]. In Yi Nam-yŏng (ed.). Hanguk-ŭi songŏ II: je 15-dae taet' ongryŏng sŏngŏ-rŭl jungsim-ŭro [Korea's Elections II: The Case of the 15th Presidential Election]. Seoul: P'urŭngil: 97-118.

Yun Seoungyi 2003. 'The Internet and the 2002 Presidential Election in South Korea.' Korea Journal 43 (2 Summer): 209-29. 